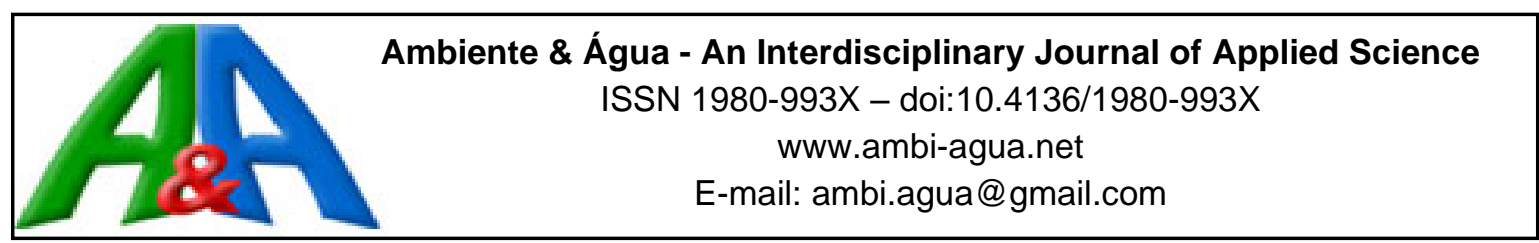

\title{
Use of organic fertilization with irrigation in coffee production in brazilian cerrado
}

\author{
ARTICLES doi:10.4136/ambi-agua.2578
}

Received: 14 May 2020; Accepted: 30 Jul. 2020

\begin{abstract}
André Luís Teixeira Fernandes ${ }^{1 *}$; Eusímio Felisbino Fraga Júnior ${ }^{2}$; Márcio José de Santana ${ }^{3}$; Reginaldo de Oliveira Silva ${ }^{4}$; Marcelo Moreira Dias ${ }^{5}$

${ }^{1}$ Pró-Reitoria de Pesquisa, Pós Graduação e Extensão. Universidade de Uberaba (UNIUBE), Avenida Nenê Sabino, $\mathrm{n}^{\circ}$ 1801, CEP: 38055-500, Uberaba, MG, Brazil.

2Instituto de Ciências Agrárias. Universidade Federal de Uberlândia (UFU), Rodovia LMG 746, km 1, s/n, Bloco 1, CEP: 38500-000, Monte Carmelo, MG, Brazil. E-mail: eusimiofraga@ufu.br

${ }^{3}$ Setor de Irrigação e Drenagem. Instituto Federal de Educação, Ciência e Tecnologia do Triângulo Mineiro (IFTM), Rua João Batista Ribeiro, n 4000, CEP: 38064-790, Uberaba, MG, Brazil.

E-mail: marciosantana@iftm.edu.br

${ }^{4}$ Departamento de Pesquisa e Desenvolvimento. Associação dos Cafeicultores de Araguari (ACA), Rodovia MG 14, KM 09, s/n, CEP: 38440-970, Araguari, MG, Brazil. E-mail: rs5059@gmail.com

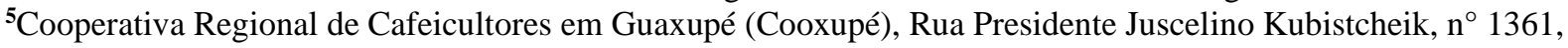
CEP: 38445-090, Guaxupé, MG, Brazil. E-mail: mmdias10@ hotmail.com

*Corresponding author. E-mail: andre.fernandes@uniube.br
\end{abstract}

\begin{abstract}
Coffee irrigation has increased in the main Brazilian coffee regions. However, in recent years, with climate change, years with water deficits greater than $150 \mathrm{~mm}$ have been observed, affecting the vegetative and productive development of the crop and also the replenishment of surface and underground springs. One practice that increases soil water retention capacity is organic fertilization. This work evaluated different combinations of irrigation and organic fertilization on the yield and quality of coffee produced in the Minas Gerais cerrado region. The treatments were: T1: total irrigation; T2: no irrigation; T3: total irrigation + organic fertilization (chicken manure, 10 ton $\mathrm{ha}^{-1}$ ); T4: no irrigation + organic fertilization (chicken manure, 10 ton $\mathrm{ha}^{-1}$ ); T5: 50\% irrigation + organic fertilization (chicken manure, 10 ton ha ${ }^{-1}$ ). After 7 harvests, it was concluded that the treatment that combined organic fertilization with application of half of the necessary irrigation presented the best yield, superior to the treatment with total irrigation and exclusively mineral nutrition.
\end{abstract}

Keywords: Coffea arabica, irrigation, poultry manure.

\section{Associação da adubação orgânica com a irrigação na produção de café no cerrado Mineiro}

\section{RESUMO}

A irrigação do cafeeiro já é realidade na maior parte das regiões produtoras do Brasil, já atingindo 300.000 ha. Na região do cerrado mineiro, grande parte das lavouras de café é irrigada. Porém, nos últimos anos, com alterações climáticas, têm sido observados anos com déficits superiores a $150 \mathrm{~mm}$, afetando o desenvolvimento vegetativo e produtivo da cultura e também o reabastecimento dos mananciais superficiais e subterrâneos. Uma prática que permite 
aumentar a capacidade de retenção de água no solo é a adubação orgânica. Dentro deste contexto, propôs-se o presente trabalho que teve como objetivo avaliar diferentes combinações de irrigação e adubação orgânica na produtividade e qualidade do café produzido no cerrado mineiro. Os tratamentos foram: T1: Irrigação total; T2: Sem irrigação; T3: Irrigação Total + Adubação Orgânica (esterco de galinha, 10 ton. $\mathrm{Ha}^{-1}$ ); T4: Sem irrigação + adubação orgânica (esterco de galinha, 10 ton. ha ${ }^{-1}$ ); T5: Irrigação 50\% + adubação orgânica (esterco de galinha, 10 ton. ha ${ }^{-1}$ ). Após 7 safras, concluiu-se que o tratamento que combinou a adubação orgânica a aplicação de metade da irrigação necessária apresentou o melhor resultado em produtividade, superior ao tratamento com irrigação total e nutrição exclusivamente mineral.

Palavras-chave: Coffea arabica, esterco de aves, irrigação.

\section{INTRODUCTION}

Coffee is one of the most consumed drinks in the world (Loftfield et al., 2018). As reported by Tverdal et al. (2020), globally coffee is the most frequently used stimulant drink and probably the safest one. Arabica coffee production provides a livelihood for millions of people worldwide (Verhage et al., 2017).

Specifically in Brazil, coffee farming is one of the most important chains in agribusiness. According to Volsi et al. (2019), there is evidence that both geographic distribution and the varieties of coffee have changed in all coffee growing regions over time. These structural changes seem to be the result of reductions in government intervention and establishing a new dynamic of coffee production and marketing in the country. Brazilian coffee farming plays an important role in generating jobs, resources and foreign currency and is quite diversified, with regional particularities (Vicente et al., 2017).

The Brazilian cerrado covers more than 200 million hectares (ha), being located in the States of Minas Gerais, Goiás, Mato Grosso, Mato Grosso do Sul, Tocantins, Bahia, Piauí, Maranhão and the Federal District, and has stood out with production exceeding 5 million sacks per hectare, mainly of Coffea arabica () L. Coffee growing in this region is characterized by productivity above the national average and by using agricultural inputs, irrigation, appropriate genotypes and mechanization, among other practices, more efficiently. The most used irrigation systems are conventional sprinkler, in mesh and central pivot) and localized (drip and modified). The climate is favorable to coffee quality because at the time of the harvest, conditions of low relative humidity occur, with the rains being concentrated in the summer. There is also, in the Cerrado, a greater amount of sunlight, especially in the autumn and winter months, which is also favorable to productivity and quality. The most planted varieties are from the Catuaí and Mundo Novo groups, and other promising materials have also been introduced with regard to productivity and resistance to drought and disease (Fernandes et al., 2012).

Coffee irrigation has increased considerably in the last 20 years due to several factors, such as the expansion of coffee production to new frontiers; the evolution of the irrigation technique; the reduction of irrigation system cost and the mentality of the coffee grower in the coffee production system, prioritizing the efficiency and quality of production (Mantovani and Soares, 2003; Santinato et al., 2008; Santinato and Fernandes, 2012, Garcia et al., 2019, Liu et al., 2018; Ho et al., 2018; Fernandes et al., 2019; Lima et al., 2019, Vicente et al., 2018). Especially in regions considered marginal with regard to water deficit, the use of irrigation has become increasingly frequent for coffee cultivation. However, the irrigation does not always follow correct sizing and management standards (Santinato and Fernandes, 2012). According to (Perdoná and Soratto, 2020), coffee can provide the farmer with a net result of 2,600.00 USD year $^{-1}$, a value similar to that found by (Fernandes et al., 2016), and which seems to be very satisfactory.

Brazil already has 300,000 ha of irrigated coffee distributed in several states, 
predominantly in Minas Gerais, Espírito Santo and Bahia; it's around 15\% of total area of coffee It is necessary to study the various coffee irrigation systems in detail and comparatively in order to make practical recommendations to coffee growers, both in the recovery of current plantations, and in the expansion of the Triângulo Mineiro's irrigated coffee cultivation (Santinato et al., 2008).

The creation and adaptation of coffee production technologies under total and supplementary irrigation are essential in order to allow high continuous and economic productivity without environmental damage (Costa et al., 2020). Most of the experimental work on coffee irrigation shows increases of 20 to 30 bags produced per hectare, regardless of the systems used and depending on the region under study (Santinato and Fernandes, 2012). However, in recent years, with climate change, there have been years with deficits greater than $150 \mathrm{~mm}$, affecting the vegetative and productive development of crops and promoting the depletion of aquifers, thus making coffee irrigation difficult.

A practice that may allow for improved water retention in the soil is organic fertilization. It constitutes a source of organic matter for the soil, with levels of nitrogen $(\mathrm{N})$, phosphorus $(\mathrm{P})$, potassium $(\mathrm{K})$ and sulfur $(\mathrm{S})$, in addition to providing micronutrients that promote beneficial effects on the soil. Siqueira et al. (2011) reported that the growth of organic coffee cultivation is considered more environmentally sustainable than the conventional way, as a new market opportunity. Friberg and Sanctuary (2018) observe that market shares for organic products are still modest, despite widespread consumer interest in purchasing organic products.

One of the most-used types of organic matter in coffee growing is poultry manure. It can be added with the use of poultry litter, which consists of peanut hay, rice straw, coffee husk and other by-products. Several other organic compounds may also be present (Matiello et al., 2010). Organic matter improves the physico-chemical and biological properties of the soil, which will directly or indirectly influence soil fertility (Malavolta, 2006). Organic matter improves aeration, permeability, soil moisture retention, availability of nutrients to plants and it increases cation exchange capacity (CEC). Within this context, this work evaluated the effects of different combinations of irrigation and organic fertilization (manure) on the productivity and quality of coffee produced in the Cerrado region of Minas Gerais.

\section{MATERIAL AND METHODS}

The experiment was set up in an experimental field of a coffee plantation belonging to the ACA (Associação dos Cafeicultores de Araguari), located on FAZENDA CHAPARRAL (CHAPARRAL FARM), on the edge of the Rodovia do Café, Km 09, municipality of Araguari (MG), latitude $18^{\circ} 38^{\prime}$, altitude $820 \mathrm{~m}$. The climate is classified by the Köppen Method, as Aw, tropical, hot and humid, with cold and dry winters. The annual precipitation was $1606.0 \mathrm{~mm}$ and the average annual temperature was $21.9^{\circ} \mathrm{C}$. The drip irrigation system has selfcompensating emitters and a flow-rate of $2.31 \mathrm{~h}^{-1}$ spaced every $0.70 \mathrm{~m}$. The coffee used was of the Catuaí IAC 62 yellow variety, aged 11 years, in a spacing of 3.70 between lines and $0.70 \mathrm{~m}$ between plants.

The meteorological data during the experiment was obtained from an automatic agrometeorological station (Davis, model Vantage Pro 2), and was installed next to the experimental plots. Through the measurements obtained by the sensors (temperature, relative humidity, wind speed and solar radiation), the evapotranspiration from the crop was estimated by the Penman Monteith Method. This method is an adaptation of the original Penman model, introducing the concepts of canopy resistance (rc) and aerodynamic resistance (ra) and is recommended by the FAO, according to Smith (1991).

In order to determine the irrigation time, the following was considered: the flow-rate of the emitters, the spacing between emitters, the spacing between lateral lines and an adjustment factor related to the reduction of the wet area, as it is localized irrigation. 
The Crop Evapotranspiration $\left(\mathrm{ET}_{\mathrm{c}}\right)$ was estimated by Equation 1:

$E T_{c}=E T_{0} \cdot K_{c} \cdot K_{m}$

In which:

$\mathrm{ET}_{0}$ - Reference Crop Evapotranspiration, estimated by the Penman Monteith Equation, with data from the automatic weather station, mm.dia ${ }^{-1}$;

$K_{c}$ - crop coefficient, decimal (Table 1)

$\mathrm{K}_{\mathrm{m}}$ - evapotranspiration adjustment factor for micro-irrigation, decimal, calculated by Equation 2.

$K_{m}=\sqrt{A S}$

in which:

As - fraction of the area shaded by the crop at noon, decimal.

The treatments were: T1: irrigation of $100 \%$ of the coffee water requirement; T2: non irrigated; T3: irrigation of $100 \%$ of the coffee water requirement + organic fertilization (poultry manure, 10 ton $\mathrm{ha}^{-1}$ ); T4: non irrigated + organic fertilization (poultry manure, 10 ton ha ${ }^{-1}$ ); T5: irrigation of 50\% of the coffee water requirement + organic fertilization (poultry manure, 10 ton $\mathrm{ha}^{-1}$ ). The design was completely randomized, with 5 treatments and 4 repetitions, totaling 20 experimental plots. Each plot contained 20 plants, with the 10 central plants being considered useful.

In regards to fertilization, 4 annual topdressing applications were carried out for all treatments following the recommendations of MAPA/ Procafé for the region (Matiello et al., 2010). The control and combat of the main pests and diseases were carried out according to recommendations proposed by Matiello et al. (2010), with Triazole fungicides paired with Strobilurin fungicides for the control of Rust (Hemileia vastatrix) and Cercosporiosis (Cercospora coffeella). For the Phoma and Ascochyta complex (Phoma spp. and Aschochyta spp), Boscalide was used. Rynaxypyr was used to control the infestation of Bicho mineiro (Leucoptera cofeeella). All cultivation, nutritional and phytosanitary treatments were similar in the evaluated treatments.

In Table 1, there is water replacement data for treatment with total irrigation, replacing the water deficit according to the climatological water balance. In the 7-year experiment period, treatments were applied with total irrigation replacement and 50\% replacement, 1406 and 703 $\mathrm{mm}$, respectively. The year with the greatest need for irrigation was 2013/2014 (Year 7), with a replacement of $274 \mathrm{~mm}$ in the total irrigation treatment, and the year with the least need for irrigation was 2014/2015 (Year 6), with a replacement of $132 \mathrm{~mm}$.

The experiment was carried out for nine years: two years designated for the formation of the crop, period of development of the plants until they became productive, and seven consecutive harvests from thereafter. The evaluations consisted of productivity and distribution measurements by sieves in each treatment. These evaluations consisted of seven harvests, harvesting only the fruit from the ten central plants of each plot when they presented a maximum of $15 \%$ green fruit. The harvested coffees had their volumes measured through a graduated container and were placed to dry until ready for processing. With the weight of the processed coffee, it was transformed into $60.0 \mathrm{~kg} \mathrm{ha}^{-1}$ processed bags per plot. For processing, samples of $1.0 \mathrm{Kg}$ dried coffee fruit were taken from each treatment and passed through a vibrating electric machine. Afterwards, classification of the sieves was done manually (mesh and with diameters of $19,18,17,16,15,14,<14)$. 
Table 1. Application depths applied in treatments with $50 *$ and $100 \% * *$ Water Replacement (WR), according to the climatological water balance.

\begin{tabular}{|c|c|c|c|c|c|c|c|c|c|c|c|c|c|c|}
\hline Meses & & Year 1 & & Year 2 & & Year 3 & & Year 4 & & Year 5 & & Year 6 & & Year 7 \\
\hline & $\begin{array}{l}\mathbf{5 0 \%} \\
\text { WR }\end{array}$ & $\begin{array}{c}100 \% \\
\text { WR }\end{array}$ & $\begin{array}{l}\mathbf{5 0 \%} \\
\text { WR }\end{array}$ & $\begin{array}{c}100 \% \\
\text { WR }\end{array}$ & $\begin{array}{l}50 \% \\
\text { WR }\end{array}$ & $\begin{array}{c}100 \% \\
\text { WR }\end{array}$ & $\begin{array}{l}\mathbf{5 0 \%} \\
\text { WR }\end{array}$ & $\begin{array}{c}100 \% \\
\text { WR }\end{array}$ & $\begin{array}{l}\mathbf{5 0 \%} \\
\text { WR }\end{array}$ & $\begin{array}{c}100 \% \\
\text { WR }\end{array}$ & $\begin{array}{l}\mathbf{5 0 \%} \\
\text { WR } \\
\end{array}$ & $\begin{array}{c}100 \% \\
\text { WR }\end{array}$ & $\begin{array}{l}50 \% \\
\text { WR }\end{array}$ & $\begin{array}{c}100 \% \\
\text { WR }\end{array}$ \\
\hline january & 0 & 0 & 0 & 0 & 0 & 0 & 0 & 0 & 0 & 0 & 0 & 0 & 0 & 0 \\
\hline february & 0 & 0 & 0 & 0 & 0 & 0 & 0 & 0 & 0 & 0 & 0 & 0 & 0 & 0 \\
\hline march & 0 & 0 & 0 & 0 & 0 & 0 & 0 & 0 & 0 & 0 & 0 & 0 & 0 & 0 \\
\hline april & 3 & 5 & 0 & 0 & 3 & 5 & 0 & 0 & 0 & 0 & 0 & 0 & 14 & 28 \\
\hline may & 5 & 9 & 10 & 20 & 3 & 5 & 0 & 0 & 3 & 5 & 0 & 0 & 14 & 27 \\
\hline june & 7 & 13 & 6 & 12 & 3 & 5 & 10 & 19 & 14 & 27 & 3 & 5 & 6 & 12 \\
\hline july & 18 & 35 & 23 & 45 & 15 & 29 & 20 & 39 & 11 & 21 & 13 & 25 & 26 & 52 \\
\hline august & 28 & 56 & 34 & 67 & 24 & 48 & 25 & 50 & 30 & 60 & 26 & 52 & 30 & 59 \\
\hline september & 27 & 53 & 4 & 7 & 18 & 35 & 26 & 51 & 19 & 38 & 11 & 21 & 48 & 96 \\
\hline october & 15 & 29 & 0 & 0 & 26 & 52 & 0 & 0 & 46 & 91 & 15 & 29 & 0 & 0 \\
\hline november & 0 & 0 & 0 & 0 & 0 & 0 & 0 & 0 & 0 & 0 & 0 & 0 & 0 & 0 \\
\hline dezember & 0 & 0 & 0 & 0 & 0 & 0 & 0 & 0 & 0 & 0 & 0 & 0 & 0 & 0 \\
\hline Total & 100 & 200 & 75,5 & 151 & 89,5 & 179 & 79,5 & 159 & 121 & 242 & 66 & 132 & 137 & 274 \\
\hline
\end{tabular}

Only the results from the largest sieves (17 or above) were presented, which obtain the best-accepted product on the market. Throughout the experiment, the nutrient content in leaves and soil was monitored annually. Data on $\mathrm{pH}$, phosphorus, potassium, organic matter, aluminum and base saturation were evaluated for all 7 years of the experiment. The collection of soils was done by plot and chemical analyses were made by joining the plots, by treatment.

In order to evaluate the normality and homoscedasticity of the data on productivity, the Kolmogorov-Smirnov and Bartlett tests were used, respectively. After verifying the normality and homoscedasticity of the data, ANOVA was used. After verifying the significance of ANOVA, the Tukey test was used for multiple comparisons between treatment averages, using the SISVAR® software (Ferreira, 2011). 


\section{RESULTS AND DISCUSSION}

In Figure 1, the monthly results of monitored meteorological variables are presented.
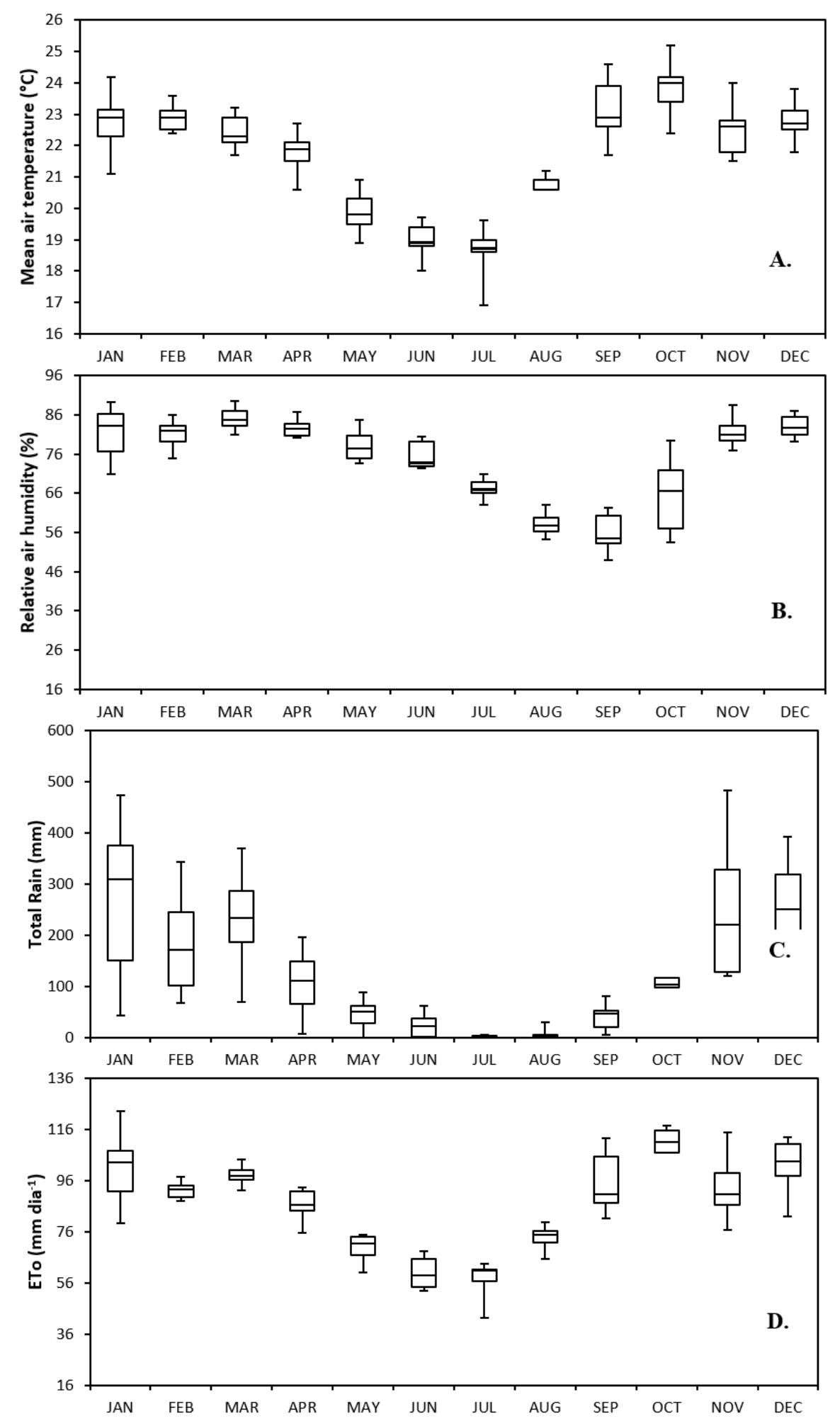

Figure 1. Box-plot graphs for mean air temperature (A), relative air humidity (B), rain (C) and reference evapotranspiration (D) for the years of the experiment.

Among the climatic parameters, temperature is a very important factor, as it has a direct impact on the development of the crop and also acts on the duration of the crop reproductive 
cycle (Pezzopane et al., 2003). The ideal annual mean temperatures for coffee development are in the range of $17^{\circ} \mathrm{C}$ to $23^{\circ} \mathrm{C}$ (Assad et al., 2001), but minimum, maximum temperature and the water deficit will increase significantly from 1980-2010 to 2040-2070 in the Arabica production regions of Brazil (Verhage et al., 2017).

The highest mean monthly temperatures were observed in October, which had a mean temperature of $23.7^{\circ} \mathrm{C}$. This month, the beginning of the spring season is characterized by an increase in the balance of radiation available in the environment and, because there is still no water vapor available in the atmosphere, much of this energy is partitioned in sensitive heat, that is, an increase in air temperature. For the data on minimum temperature, mean values of $18.7^{\circ} \mathrm{C}$ were observed in June and July. In the Brazilian Arabica coffee producing regions, the mean temperature after flowering is projected to increase by $1.3^{\circ} \mathrm{C}$, while the annual water deficit is projected to increase by $54 \mathrm{~mm}$ (Vergage et al., 2017). As a result, yield losses due to high air temperatures and water deficit are projected to increase.

In the summer months and early autumn, the highest relative humidity (RH) was observed, always above $80 \%$; between August and September, the lowest RH values occurred, between 56 and $58 \%$.

The months of December and January were the rainiest, but with considerable variability between the years monitored due to the occurrence of periods of unusually dry weather in otherwise rainy months. The months of July and August had the lowest rainfall.

In Figure 2, the water balance is shown for the irrigated coffee during the experiment, with total replacement of the coffee tree's needs. Considering the irrigation performed in the treatment with total irrigation, the monthly storage (MS) did not exceed the threshold of $40 \%$ of the available water capacity (AWC), indicating good water conditions for the plants.

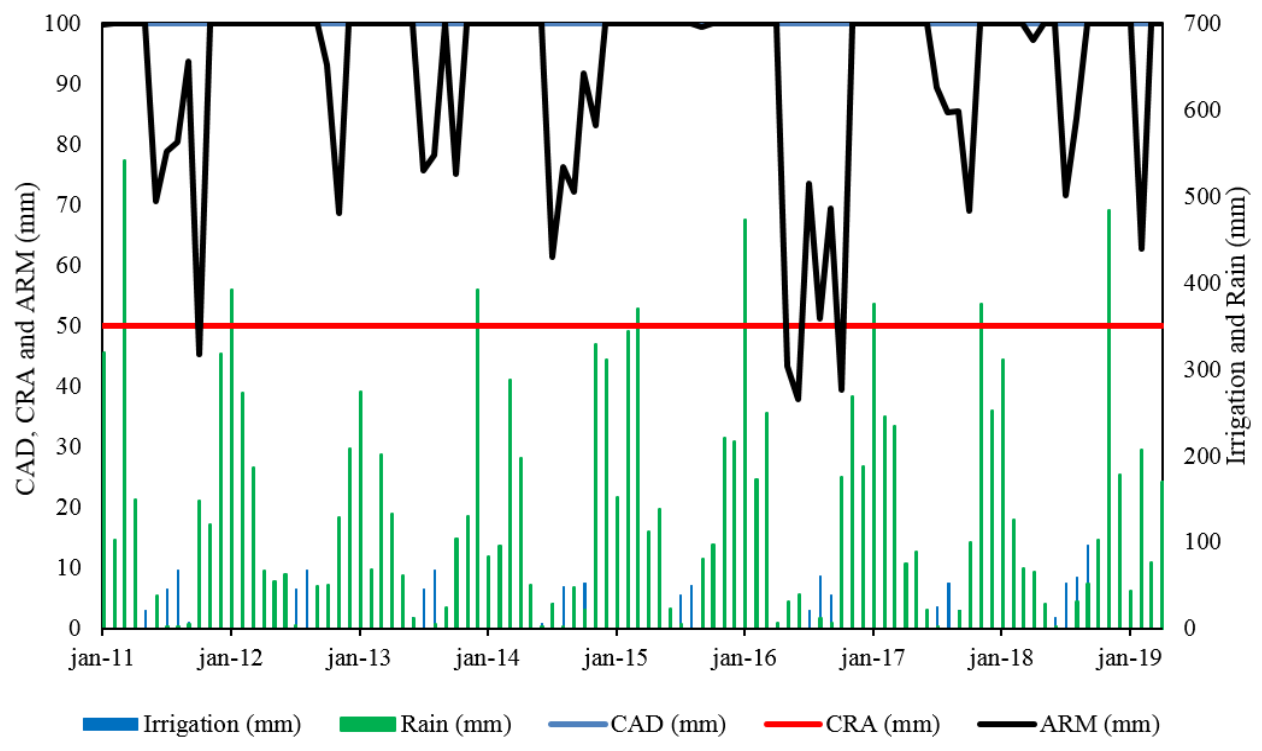

Figure 2. Account of the sequential climatological water balance for drip irrigated coffee. $\mathrm{AWC}=100 \mathrm{~mm}$.

In Table 2, productivity results are shown per year for the different treatments. Assigning the value of $100 \%$ for the treatment with total irrigation (Treatment 1), in seven harvests, it was observed that the control without irrigation produced 56\% less (19.4 processed bags ha $\left.{ }^{-1}\right)$, corroborating what was reported by DaMatta and Ramalho (2006), who described the relationship between water and the coffee tree studied by several researchers in recent decades. Coffee plant productivity is strongly influenced by an adequate supply of water (Sakai et al., 2015). The reduction in coffee productivity caused by water deficit is reported in the literature by many other authors, such as Silva et al. (2008), Fernandes et al. (2016), Gomes et al. (2007), 
Chemura (2014), among others. Irrigation has a significant effect on coffee crop water deficit (Verhage et al., 2017).

Table 2. Productivity for different treatments, 7 harvests, Izidoro Bronzi Experimental Field, Araguari - MG. 1 bags produced - $60 \mathrm{~kg}$ of green coffee.

\begin{tabular}{|c|c|c|c|c|c|c|c|c|}
\hline \multirow{2}{*}{ Treatments } & \multicolumn{8}{|c|}{ Production and Average Seven Harvests - Bags produced/ha. } \\
\hline & $2009 / 2010$ & $2010 / 2011$ & $2011 / 2012$ & $2012 / 2013$ & $2013 / 2014$ & $2014 / 2015$ & $2015 / 2016$ & Mean \\
\hline $\begin{array}{l}\text { T1: Total } \\
\text { irrigation }\end{array}$ & $21.8 \mathrm{a}$ & $53.8 \mathrm{c}$ & $46.7 b$ & $36.2 b$ & $58.6 \mathrm{a}$ & $36.8 \mathrm{ab}$ & $58.5 \mathrm{a}$ & 44.6b \\
\hline T2: No irrigation & $15.7 \mathrm{~d}$ & $37.2 \mathrm{e}$ & $18.3 \mathrm{~d}$ & $5.2 \mathrm{c}$ & $29.9 \mathrm{c}$ & $9.2 \mathrm{c}$ & $20.2 d$ & 19.4d \\
\hline $\begin{array}{l}\text { T3: Total } \\
\text { irrigation }+ \\
\text { Organic fertilizer } \\
(\text { chicken manure, } \\
10 \text { ton }^{-1} \text { ) }\end{array}$ & $19.6 \mathrm{c}$ & $62.5 \mathrm{a}$ & $55.0 \mathrm{a}$ & $54.6 \mathrm{a}$ & $53.2 \mathrm{ab}$ & $49.7 \mathrm{a}$ & $57.5 \mathrm{a}$ & $\mathbf{5 0 . 3 a}$ \\
\hline $\begin{array}{l}\text { T4: No irrigation } \\
\text { + organic } \\
\text { fertilizer }\end{array}$ & $20.5 b c$ & $42.1 \mathrm{~d}$ & $35.5 \mathrm{c}$ & $25.6 \mathrm{~b}$ & $35.3 \mathrm{c}$ & $29.4 b$ & $32.9 \mathrm{c}$ & $31.6 \mathrm{c}$ \\
\hline $\begin{array}{l}\text { T5: Irrigation } \\
50 \%+\text { organic } \\
\text { fertilizer }\end{array}$ & $20.8 \mathrm{ab}$ & $59.7 b$ & $58.6 \mathrm{a}$ & $51.0 \mathrm{a}$ & $49.2 b$ & $43.7 \mathrm{ab}$ & $54.3 b$ & 48.2a \\
\hline C.V.\% & 18.3 & 9.5 & 12.8 & 15.0 & 6.8 & 15.11 & 12.51 & 12.22 \\
\hline
\end{tabular}

When adding 10 ton $\mathrm{ha}^{-1}$ of chicken manure (Treatment 4), the reduction was smaller, only $29 \%$ compared to total irrigation without organic matter. According to Chemura (2014), organic matter in the soil plays an important role in moisture retention and, therefore, the use of organic fertilizers is considered a strategy for adapting to climate change.

By adding organic fertilizer to the treatment with total irrigation (Treatment 3), it was possible to obtain the highest productivity over 7 years, 50.3 bags produced per hectare, $13 \%$ above the treatment with total irrigation without organic fertilizer. Due to the higher concentration of organic matter, nutrients and soil moisture levels, the superficial layers (0-10 and $10-20 \mathrm{~cm})$ tend to have a higher root concentration, optimizing water and nutrient absorption (Vicente et al., 2017).

Another extremely satisfactory result was obtained by using only half of the necessary irrigation, $50 \%$ (Treatment 5), with organic fertilizer, which allowed an average of 48.2 processed bags per hectare in 7 harvests, results justified by Chemura (2014), who mentioned that the interaction between nutrient sources and irrigation levels is very important, especially in the context of reducing production costs and adapting to climate change. When adding 10 ton $\mathrm{ha}^{-1}$ of organic fertilizer was added, productivity was $8 \%$ higher than when compared to the treatment with only total irrigation; however, there was no statistical difference between the two treatments, using half of the necessary water. The effect of organic matter on coffee productivity was confirmed by Fernandes et al. (2013), who concluded that the use of chicken manure as a source of $\mathrm{N}, \mathrm{P}, \mathrm{K}$ and $\mathrm{S}$ is feasible in reducing these nutrients in the exclusive mineral fertilization of coffee. The contribution of organic residues, such as the chicken manure used in this test, associated with the humification process, promotes an improvement in soil attributes and guarantees the farmer the maintenance of the productive system (Coelho et al., 2013).

Analyzing the classification by sieves and considering sieves 17 or above, which are related to the larger seeds and generally associated with a better final product price, the best results were obtained with irrigated treatments $(100 \%$ of the coffee water requirement + organic matter) and irrigation of $50 \%$ of the coffee water requirement + organic matter, with 
percentages of 32.2 and $32.0 \%$, respectively, with larger results in 11 and $10 \%$, respectively, when the treatment is considered standard (total irrigation, without organic matter - Treatment 1). The treatment without irrigation and without organic matter (T2) had $42 \%$ less fruit with the largest sieves (17 or above), with a total of $16.8 \%$. The use of irrigation increases coffee fruit size. The finding of increased coffee grain size was also reported by Fernandes et al. (2019), Rezende et al. (2006), Soares et al. (2005), Teodoro et al. (2005) and Miranda et al. (2020).

Regarding $\mathrm{pH}$, the highest values were obtained in treatments with organic matter, Treatments 3 to 5, with values of 5.8; 5.4 and 5.7, respectively, which are within the range considered standard for coffee cultivation by Santinato et al. (2008). The same happened with the phosphorus values, with the highest values occurring with the use of organic fertilizer, with values 63,75 and $81 \mathrm{mg} \mathrm{dm}^{-3}$. For potassium, the highest mean values were observed in Treatments 3 and 5, with 176 and $149 \mathrm{mg} \mathrm{dm}^{-3}$ of potassium, respectively. As expected, the highest values of organic matter in the soil were obtained with treatments that used organic sources, with averages over 7 years of $3.9 ; 3.7$ and $3.9 \mathrm{dag} \mathrm{Kg}^{-1}$, compared to treatments without organic matter ( 1 and 2), with values of $3.1 \mathrm{dag} \mathrm{Kg}^{-1}$. The lowest aluminum values in the soil were observed in treatments with organic matter (Treatments 3,4 and 5), with values of 0.2. 0.1 and $0.0 \mathrm{cmolc} \mathrm{dm}^{-3}$, compared to treatments without organic matter ( 1 and 2), with values of 0.5 and 0.4 , respectively. Finally, base saturation was also higher in treatments using chicken manure, with values of 51, 52 and 51, respectively, for Treatments 3, 4 and 5. This was higher than Treatments 1 and 2, without organic matter, with values of 42 and $40 \%$ (Figure 3).

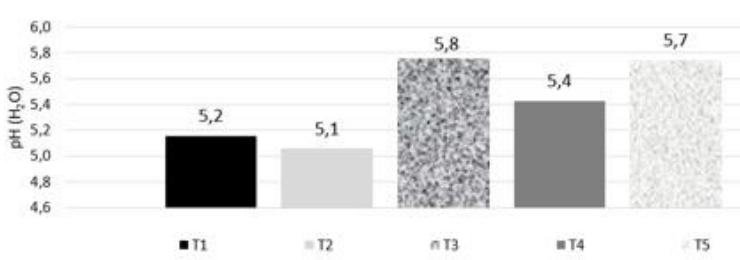

(a)

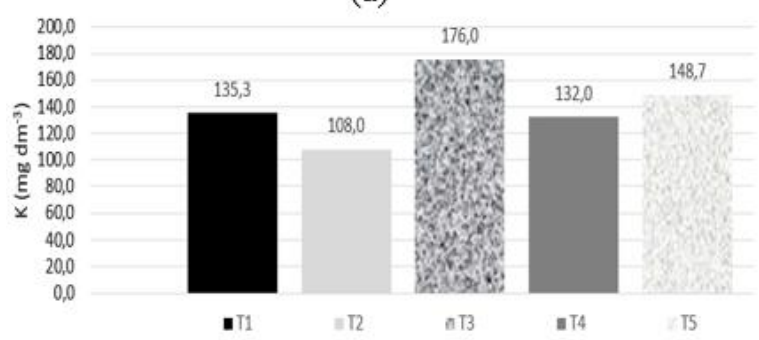

(c)
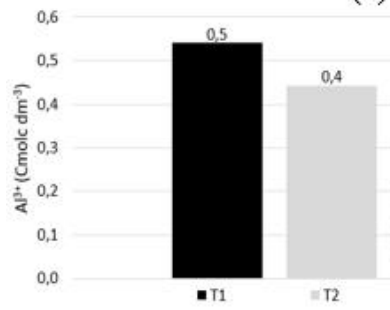

(e)

T1: Total irrigation

A T3: Total Irrigation + organic nutrition

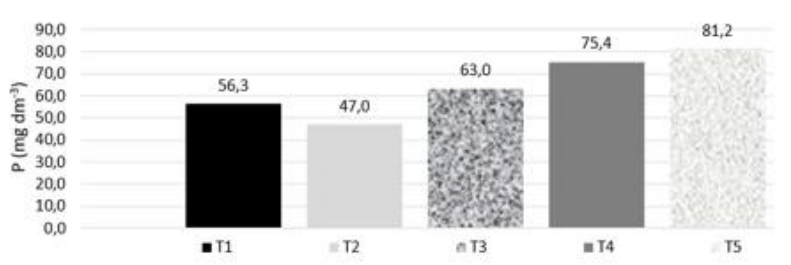

(b)

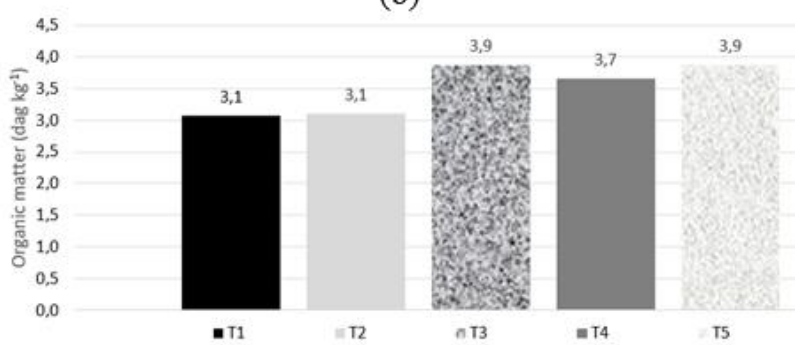

(d)

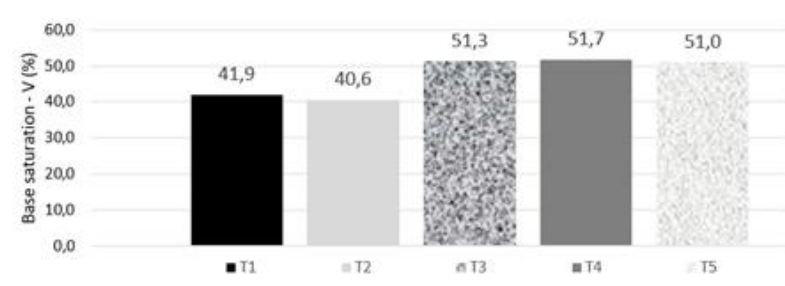

(f)

T2: Without irrigation

- T4: Without irrigation + organic nutrition

T5: Irrigation $50 \%$ + organic matter

Figure 3. pH Values (a), Phosphorus - P, in Melich (b), Potassium - K (c), Organic matter (d), Aluminum - $\mathrm{Al}$ (e) and base saturation - V\% (e) averages per treatment after seven harvests, Izidoro Bronzi Experimental Field, Araguari - MG. 


\section{CONCLUSIONS}

After 7 harvests, it can be concluded that:

- The use of organic matter allows the reduction in the irrigation depth applied to the coffee crop, which may allow the coffee grower to irrigate twice the area with the same availability of water but with about a $4 \%$ reduction in grain size.

- Adding organic matter to the irrigated treatments allowed for the harvest of fruit from larger sieves.

- The use of poultry manure, associated with or without irrigation, allowed for the best soil chemical results.

\section{REFERENCES}

ASSAD, E. D. et al. Zoneamento agroclimático para a cultura de café (Coffea arabica L.) no estado de Goiás e sudoeste do estado da Bahia. Revista brasileira de Agrometeorologia, v. 9, n. 3, p. 510-518, 2001.

CHEMURA, A. The Growth Response of Coffee (Coffea arabica L) Plants to Organic Manure, Inorganic Fertilizers and Integrated Soil Fertility Management under Different Irrigation Water Supply Levels. International Journal of Recycling of Organic Waste in Agriculture, v. 3, n. 2, p. 3-11, 2014. https://doi.org/10.1007/s40093-014-0059-X

COELHO, M. S. et al. Qualidade da matéria orgânica de solos sob cultivo de café consórciado com adubos verdes. Revista Brasileira de Ciência do Solo, v. 37, n. 6, p. 1576-1586, 2013. https://doi.org/10.1590/S0100-06832013000600014

COSTA, J. O.; COELHO, R. D.; BARROS, T. H. S.; FRAGA JR., E. F.; FERNANDES, A. L. T. Canopy Thermal Response to Water Deficit of Coffee Plants under Drip Irrigation. Irrigation and Drainage, v. 69, n. 3, p. 472-482, 2020. https://doi.org/10.1002/ird.2429

DAMATTA, F. M.; RAMALHO, J. D. C. Impacts of Drought and Temperature Stress on Coffee Physiology and Production: A Review. Brazilian Journal of Plant Physiology, 2006. https://doi.org/10.1590/S1677-04202006000100006

FERNANDES, A. L. T.; SANTINATO, F.; FERREIRA, R. T.; SANTINATO, R. Adubação orgânica do cafeeiro, com uso do esterco de galinha, em substituição à adubação mineral. $\begin{array}{llllllll}\text { Coffee } & \text { Science, } & \text { v. } & 8, & \text { n. } & 4, & \text { p. } & 486-499,\end{array}$ http://www.sbicafe.ufv.br/handle/123456789/8003

FERNANDES, A. L. T.; SILVA, R. de O.; SALDANHA, L.; BETINI, M. O.; BROETTO, F. Effect of seaweed extract formulation on coffee plants at different irrigation levels. Asian Academic Research Journal of Multidisciplinary, v. 6, p. 60-74, 2019.

FERNANDES, A. L. T.; TAVARES, T. O.; FERREIRA, R. T.; SANTINATO, R. Technical and Economic Viability of Drip Irrigation of Coffee in Araxá, MG. Coffee Science, v. 11, n. 3, p. 347-58, 2016. https://doi.org/10.25186/cs.v11i3.1090

FERNANDES, A. L. T.; PARTELlI, F. L.; BONOMO, R.; GOLYNSKI, A. A moderna cafeicultura dos cerrados brasileiros. Pesquisa Agropecuária Tropical, v. 42, p. 231240, 2012. 
FERREIRA, D. F. Sisvar: a computer statistical analysis system. Ciência e Agrotecnologia, v. 35, n. 6, p. 1039-1042, 2011. https://doi.org/10.1590/S1413-70542011000600001

FRIBERG, R.; SANCTUARY, M. Market Stealing and Market Expansion: An Examination of Product Introductions in the Organic Coffee Market. Environmental Economics and Policy Studies, v. 20, n. 2, p. 287-303, 2018. https://doi.org/10.1007/s10018-017-0194-5

GARCIA, F. H. S. et al. Análise fisiológica em mudas de cafeeiro com cercosporiose submetida a diferentes lâminas de irrigação. Summa Phytopathology, v. 45, p. 83-88, 2019. https://doi.org/10.1590/0100-5405/185711

GOMES, N. M; LIMA, L. A.; CUSTÓDIO, A. A. Vegetative Growth and Yield of Irrigated Coffee in Southern Region of State of Minas Gerais - Brazil. Revista Brasileira de Engenharia Agrícola e Ambiental, v. 11, n. 6, p. 564-70, 2007. https://doi.org/10.1590/S1415-43662007000600003

HO, T. Q.; HOANG, V. N.; WILSON, C.; NGUYEN, T. T. Eco-efficiency analysis of sustainability-certified coffee production in Vietnam. Journal of Cleaner Production, v. 183, p. 251-2560, 2018. https://doi.org/10.1016/j.jclepro.2018.02.147

LIMA, J. V. O.; FERNANDES, A. L. T.; FRAGA JR, E. F.; CRUZ, P. O. H.; CRUZ, J. P. H.; SANTANA, M. J. Irrigation management with IoT sensors in three phenological phases of coffee crop. Asian Academic Research Journal of Multidisciplinary, v. 6, p. 78-96, 2019 .

LIU, X.; QI, F. L.; YANG, Q.; YU, L. Impacts of regulated deficit irrigation on yield, quality and water use efficiency of Arabica coffee under different shading levels in dry and hot regions of southwest China. Agricultural water management, v. 204, p. 192-300, 2018. https://doi.org/10.1016/j.agwat.2018.04.024

LOFTFIELD, E.; CORNELIS, M. C.; CAPORASO, N.; YOU, K.; SINHA, R.; FREEDMAN, $\mathrm{N}$. Association of coffee drinking with mortality by genetic variation in caffeine metabolism. JAMA International Medicine, v. 178, n. 8, p. 1086-1097, 2018. https://dx.doi.org/10.1001/jamainternmed.2018.2425

MALAVOLTA, E. Manual de nutrição de plantas. São Paulo: Agronômica Ceres, 2006. 631 p.

MANTOVANI, E. C.; SOARES, A. R. Irrigação do cafeeiro: informações técnicas e coletânea de trabalhos. Viçosa: Associação dos Engenheiros Agrícolas de Minas Gerais; UFV; DEA, 2003. 260p. (Boletim Técnico, 8).

MATIELLO, J. B. et al. Cultura do café no Brasil: manual de recomendações. Varginha: Fundação Procafé, 2010. 542 p.

MIRANDA, F. L.; DRUMOND, L. C. D.; RONCHI, C. P. Synchronizing coffee blossoming and fruit ripening in irrigated crops of the Brazilian Cerrado Mineiro Region. Australian Journal of Crop Science, v. 14, n. 4, p. 605-613, 2020.

PERDONÁ, M. J., SORATTO, R. P. Arabica Coffee-Macadamia Intercropping: Yield and Profitability with Mechanized Coffee Harvesting. Agronomy Journal, v. 112, n. 1, p. 429-440, 2020. https://doi.org/10.1002/agj2.20016

PEZZOPANE, J. R. M. et al. Escala para avaliação de estádios fenológicos do cafeeiro arábica. Bragantia, v. $62, \quad$ n. 3, p. 499-505, 2003. https://doi.org/10.1590/S000687052003000300015 
REZENDE, F. C.; OLIVEIRA, S. R.; FARIA, M. A.; ARANTES, K. R. Características produtivas do cafeeiro (Coffea arabica L. cv., Topázio MG-1190) recepado e irrigado por gotejamento. Coffee Science, v. 1, n. 2, p. 103-110, 2006. http://www.sbicafe.ufv.br/handle/123456789/3897

SAKAI, E.; BARBOSA, E. A. A.; SILVEIRA, J. M. de C.; PIRES, R. C. de M. Coffee productivity and root systems in cultivation schemes with different population arrangements and with and without drip irrigation. Agricultural Water Management, v. 148, p. 16-23, 2015. https://dx.doi.org/10.1016/j.agwat.2014.08.020

SANTINATO, R.; FERNANDES, A. L. T. Cultivo do cafeeiro irrigado por gotejamento. 2. ed. Uberaba: Universidade de Uberaba, 2012. 378 p.

SANTINATO, R.; FERNANDES, A. L. T.; FERNANDES, D. R. Irrigação na Cultura do Café. 2. ed. Belo Horizonte: O Lutador, 2008. 476 p.

SILVA, C. A. da; TEODORO, R. E. F.; MELO, B. Produtividade e Rendimento Do Cafeeiro Submetido a Lâminas de Irrigação. Pesquisa Agropecuária Brasileira, v. 43, n. 3, p. 387-394, 2008. https://doi.org/10.1590/S0100-204X2008000300014

SIQUEIRA, H. M. L. de; SOUZA, P. M.; PONCIANO, N. J. Café Convencional versus Café Orgânico: Perspectivas de Sustentabilidade Socioeconômica Dos Agricultores Familiares Do Espírito Santo. Revista Ceres, v. 58, n. 2, p. 155-60, 2011. https://doi.org/10.1590/s0034-737x2011000200004

SOARES, A. R.; MANTOVANI, E. C.; RENA, A. B.; COELHO, M. B.; SOARES, A. A. Avaliação do efeito da aplicação de diferentes lâminas de irrigação na produtividade do cafeeiro para a região do cerrado de Minas Gerais. In: SIMPÓSIO BRASILEIRO DE PESQUISA EM CAFEICULTURA IRRIGADA, 7., 2005, Araguari. Anais[...] Araguari: Associação dos Cafeicultores de Araguari, 2005. p. 50-53.

TEODORO, R. E. F.; MELO, B.; CARVALHO, H. P.; GUIRELLI, J. E.; BENEDETTI, T. C.; BUENO, M. R. Influência de diferentes lâminas de irrigação nos parâmetros de produção do cafeeiro cultivado em região de cerrado. In: SIMPÓSIO BRASILEIRO DE PESQUISA EM CAFEICULTURA IRRIGADA, 7., 2005, Araguari. Anais[...] Araguari: Associação dos Cafeicultores de Araguari, 2005. p. 161-165.

TVERDAL, A.; SELMER, R.; COHEN, J. M.; THELLE, D. S. Coffee consumption and mortality from cardiovascular diseases and total mortality: does the brewing method matter? European Journal of Preventive Cardiology, p.1-8, 2020. https://doi.org/10.1177\%2F2047487320914443

VERHAGE, F. Y.; ANTEN, N. P. R.; SENTELHAS, P. C. Carbon dioxide fertilization offsets negative impacts of climate change on Arabica coffee yield in Brazil. Climatic Change, v. 144, p. 671-685, 2017. https://doi.org/10.1007/s10584-017-2068-z

VICENTE, M. R.; MANTOVANI, E. C.; FERNANDES, A. L. T.; NEVES, J. C. L.; FIGUEIREDO, E. M.; DELAZARI, F. T. Spacial distribution of fertigated coffee root system. Ciência e Agrotecnologia, v. 41, p. 72-80, 2017. https://doi.org/10.1590/141370542016411021316 
VICENTE, M. R.; MANTOVANI, E. C.; FERNANDES, A. L. T.; NEVES, J. C. L.; FIGUEREDO, E. M. Development and production of fertigated coffee trees in the West Region of Bahia, Brazil. Coffee Science, v. 13, p. 90-97, 2018. http://dx.doi.org/10.25186/cs.v13i1.1383

VICENTE, M. R.; MANTOVANI, E. C.; FERnANDES, A. L. T.; NEVES, J. C. L.; DELAZARI, F. T.; FIGUEREDO, E. M. Effects of Irrigation on the Production and Development of Coffee in the West Region of Bahia. Coffee Science, v. 12, n. 4, p. 544551, 2017. https://doi.org/10.25186/cs.v12i4.1367

VOLSI, B.; TELLES, T. S.; CALDARELLI, C. E.; CAMARA, M. R. G. The Dynamics of Coffee Production in Brazil. PLoS ONE, v. 14, n. 7, p. 1-15, 2019. https://doi.org/10.1371/journal.pone.0219742 